\title{
Are current accountability frameworks appropriate for degree apprenticeships?
}

\begin{abstract}
Purpose

In 2015 the Conservative-led government announced their plan to increase the number of people participating in apprenticeship to 3 million by 2020. As part of this plan there is to be an expansion of the number of degree level apprenticeships, with the government suggesting that these should be seen as a real alternative to university. Despite the government's propaganda of an alternative to university, higher education institutions (HEI) have a pivotal role to play in both the development and delivery of degree level apprenticeships. However, the accountability for the success of degree level apprenticeships remains unclear. The purpose of this paper is, therefore, to consider whether existing outcome-based notions of accountability are appropriate, given the tri-partite relationship involved in apprenticeship delivery.
\end{abstract}

\section{Design/methodology/approach}

The paper provides an analysis of current notions of outcome-based accountability contextualised through the degree apprenticeship programme.

\section{Findings}

The paper illustrates that outcome-based accountability frameworks do little to support the delivery of degree level apprenticeships suggesting that there needs to be a shift to a holistic approach where student success forms just one element of an accountability framework. A conclusion is subsequently made that current accountability frameworks may end in an unnecessary confusion regarding the roles and responsibilities of individual contributors associated with degree apprenticeships, resulting in a missed opportunity to maximise on the value arising from the tri-partite delivery relationship.

\section{Originality/value}

This paper provides an original perspective involving accountability associated with degree apprenticeship programmes in the UK.

\section{Keywords}

Degree level apprenticeships; accountability frameworks; quality assurance; outcomes; audit. 


\section{Introduction}

For the past 30 years, a variety of work-based learning has been labelled as an apprenticeship with a majority of these sitting under the heading of further education (FE). As a sector further education occupies an awkward place in the UK education system. Designed to deliver training (both vocational and academic) up to sub-degree level to individuals who have completed their compulsory schooling [akin to US community colleges or Australian technical colleges]; however, over the past decade the boundaries between FE and schools and universities have become increasingly blurred, with FE progressively having a role in the delivery of school curriculum as well as in degree level education. Unlike schools which are compulsory and protected by law; and universities which are selective and protected by the monarchy via Royal Charter (or for newer universities by Act of Parliament - Further and Higher Education Act 1992, or by Privy Council approval), further education institutions have none of these protections. This makes FE the first place to which governments of all sides turn to when they need to make a change with direct impact.

Until recently, apprenticeships were largely delivered at levels 2 and 3 by further education colleges and training providers making them equivalent to GCSEs (state exams usually taken at age 16) and A-levels (exams taken at age 18). Nonetheless, the government's aspiration to engage 3 million people in apprenticeships has resulted in an expansion of the current apprenticeship programme to include degree level apprenticeships. What became apparent with such developments was that existing education-based accountability frameworks, which were primarily designed for the compulsory and post-compulsory education sectors, do not adequately cover higher education provision regardless of where programmes are being delivered.

This paper explores whether existing notions of accountability which are predicated on outcome-based measures and are the instrument of choice by many western governments can be applied to degree level apprenticeships. In doing so, the paper explores the disparities in the higher education provision traditionally delivered by further education organisations and awarded by national awarding organisations; and higher education institutions which can award their own qualifications.

Despite the differences in the structure of qualifications which are a fundamental element of the degree level apprenticeships, this paper highlights a further concern regarding whether current funding arrangements are sustainable given the successive reductions for both further and higher education sectors. Currently, funding for degree level apprenticeships resides with the Skills Funding Agency which funds post-19 learning but not prescribed higher education. It may be that the government's new Apprenticeship Levy (BIS, 2015) will provide longer term funding stability but, at the moment, little is known about the levy scheme so it is impossible to ascertain its potential impact.

The paper then examines current notions of accountability and whether outcome-based accountability measures, the preferred choice of government, are indeed the most effective given that apprenticeships are a collaboration between the training provider (typically a university), the employer (an organisation which through the apprenticeship levy scheme will also become the commissioner of apprenticeship places) and the learner.

\section{The education and policy context for degree apprenticeships}


The Conservative government has committed to increasing the number of people engaged in apprenticeships to 3 million by 2020 (BIS, 2015), continuing previous government's efforts to exploit this enduring model of learning in order to meet policy objectives (Brookmann, Clarke \& Winch, 2010).

Resulting changes in the labour market, the impact of youth unemployment and publications such as the Leitch Review of Education and Skills (HM Treasury, 2006) have propelled work-based learning into the fore.

The Leitch Review (HM Treasury, 2006) highlighted the need to raise the level of skills within the nation's workforce and called for more vocational programmes at level 5 and beyond. More recently a UK Commission for Employment and Skills report (UKCES, 2015) highlights the ongoing skills shortage within the UK and continues to advocate apprenticeships as a means of addressing the skills gap (UKCES, 2012). This commitment was reinforced by Delebarre (2015) who highlights the context and focus placed on apprenticeships by the UK government and the further expansion of apprenticeships demonstrated with the announcement of a Higher Apprenticeship Fund. This fund offered $f 25 \mathrm{~m}$ to projects that would develop and pilot the next generation of apprenticeships (National Apprenticeship Service [NAS], 2011). Working in collaboration with employers and sector based representative organisations, these new Trailblazer apprenticeships as they became known, sought to develop a range of new apprenticeships with the curriculum content derived by employers rather than education providers (BIS, 2016).

Such focus is being placed on apprenticeships by the UK government that the Enterprise Act 2016 protects the term 'Apprenticeship' in order not to be misused by organisations offering training which does not meet the requirements of an apprenticeship framework. By protecting it, the term apprenticeship is being afforded the same security as other key terms in education, such as degree and university and it also highlights to employers, learners and stakeholders that the training offered must comply with the requirements of an apprenticeship framework.

In addition to this, publicly [state] funded organisations will have to, by law under section 24(1) of the Enterprise Act 2016, employ a specific number of apprentices which will help to ensure that government meets its aspiration of 3 million apprenticeships by 2020. This raises further questions, which are beyond the scope of this paper regrading whether organisations are taking on apprentices in order to meet their future skills need or because they are compelled to under legislation. Saying that, the Enterprise Act 2016 does not provide any information on non-compliance with the requirement to employ a specific number of apprentices which suggests that this may simply be a non-enforceable duty on employers with no punitive measures.

Despite the ongoing debate around the rationale for apprenticeship targets, the aspiration needs to the support of not only education providers, but employers too. Local Enterprise Partnerships (LEPS) which were established in 2011 by the government to work with local councils and employers in supporting the local economy. Education and Skills are a key strand in all 49 LEPS and as such have a role to play in promoting apprenticeships. Furthermore, the government's City Deal initiative, established by the Localism Act 2011, was designed to empower the economically more significant cities in the UK to take responsibility for their own economic growth. As part of this, apprenticeships were seen as a key feature in the City Deal programme with over 37,000 new apprenticeships being established.

All of the above highlights the way in which apprenticeships are permeating through government policy. 
The development of higher (levels 4 through to 7) and degree level (levels 6 and 7) apprenticeships mirrors the concept of already existing apprenticeships which are work-based but coupled with the development of underpinning knowledge in order to support a student's learning. Key to the success of new apprenticeships is ensuring a clear vocational pathway from existing intermediate (level 2) and advanced (level 3) programmes through to 'professional status' (Williams \& Hanson, 2011, p.16). The development of higher and degree level apprenticeships should send a strong message to universities that they ought to be closely involved in their developments, as they are uniquely placed to contribute expertise and take advantage of the opportunities offered. A view which is echoed by Universities UK (2016) which in addition suggested that degree level apprenticeships are 'a way for universities to diversify their offer and develop alternatives to traditional full-time on-campus study' (pg.2). At no point is there any mention of apprenticeships being a way of combating the decline in the numbers participating in part-time higher education (Hillman, 2015).

These new apprenticeships have been presented as equivalents to undergraduate degrees and the then Skills Minister John Hayes suggested, 'by radically increasing the number of degree-level apprenticeships we are putting practical learning on a level footing with academic study' (BIS, 2012). Yet as the OECD notes 'apprenticeships are often seen as a poor second class choice relative to more general academic studies' (OECD, 2014, pg. 3) and go onto suggest that more needs to be done globally to improve the recognition and value of apprentices and remove the restrictions to who can access them. This could pose a substantive threat to existing higher education provision, although they also offer an opportunity to establish coherence between university qualifications and professional sector recognition (Anderson, Bravenboer \& Hemsworth, 2012).

Despite the apparent equivalence between higher apprenticeships and higher education qualifications, caution must be noted. Many of the current higher apprenticeship frameworks are credit rated on the qualifications and credit framework (QCF), a UK system that benchmarks qualifications against a series of levels ranging from entry (pre-GCSE) to level 8 (doctoral level). An equivalent framework exists for qualifications for the European Higher Education Area, as defined by the Bologna process which was established in 1999 in order to foster student mobility and employability through a system of ensuring equivalency between higher education qualifications. In the UK credits are achieved through the completion of learning, with 10 credits equating to 100 hours of learning. All types of apprenticeship include the completion of competency (on the job) and knowledge (off the job) qualifications or a qualification that integrates both elements.

Until 2013, all apprenticeships had to include a minimum amount of 'off the job' learning, in line with the framework set out in the Apprenticeship, Skills Children and Learning (ASCL) Act 2009. The introduction of the Specification of Apprenticeship Standards for England (SASE) in 2013 introduced a minimum credit value for higher apprenticeships of 90 credits (equating to 900 hours of learning). This is an increase from the previous minimum requirement of 37 credits or 370 hours of learning.

Even so, this is likely to be significantly less than existing degree programmes which are credit rated on the framework for higher education qualifications (FHEQ). Typically, degrees require 360 credits, based on the FHEQ, with 10 credits equating to 100 hours of learning. This means that 360 credits are equivalent to 3,600 hours of learning over 3 years, significantly more than a qualification of the same level on the QCF. 
Fuller and Unwin (2012) suggest that the use of the QCF for higher level apprenticeship qualifications can lead to a 'vocational glass ceiling' (p.6) for learners due to the relatively small number of credits required, in comparison to the FHEQ. This has the potential to lead to misleading claims about the extent to an individual's achievement. For example, qualifications at level 6 on the QCF and FHEQ require very different amounts of study.

This poses an interesting dilemma for those who are developing higher and degree level apprenticeships, as a majority of existing apprenticeship programmes have been developed and delivered by FE providers operating on the QCF. For instance, the existing level 5 apprenticeship for life science and chemical science professionals requires students to complete an Edexcel (an awarding organisation, independent of further and higher education institutions, which offers qualifications that can be delivered by education providers) Higher National Diploma (HND) in Chemical Science for Industry. This two-year level 5 qualification is credit rated on the QCF and delivered by FE colleges with funding provided for 960 hours worth of learning over two years. Higher National Diplomas are largely recognised as equivalent to the first two years of a degree programme, yet if a university were to develop an equivalent two-year programme thus offering direct entry into year 3 of a degree, they would have to use the FHEQ which would require a programme of 240 credits equating to 2400 hours of learning. Automatically, there is disparity within the apprenticeship system depending on which organisation is awarding the qualification element of the apprenticeship framework.

Over the past 15 years, Foundation degrees validated by universities and frequently delivered by FE colleges have become a more prominent feature of the qualifications landscape. These qualifications, modelled on the US Associate Degree programme, required employer engagement in the development of the curriculum ensuring that it meets the needs of the employer and the local economy as well as offering a progression route to a full degree. Examples of Foundation degrees that have had significant employer engagement in their development are those which have been pioneered by Rolls Royce and Ford and validated by the universities of Derby and East London (Anderson, Bravenboer \& Hemsworth, 2012).

Until recently, foundation degrees required validation through a university or similar institution with degree awarding power which has the advantage over national awarding organisations such as Edexcel as the programmes are be designed to meet a specific local need as well as being credit rated on the FHEQ, so more aligned to existing higher education provision. More recently, FE colleges have been able to apply for foundation degree awarding powers and this is something that has only been conferred on five colleges: Newcastle College group; Hull College group; New College, Durham; Grimsby Institute of Further and Higher Education; and the Warwickshire College group.

Despite this advance in the role of FE colleges by being able to validate foundation degrees, it is too early to determine whether there is the potential for a decline in university involvement which could intensify the artificial vocational and academic divide.

Regardless of the aforementioned discussion on the structure of degree level apprenticeships, there is a wider debate that needs to be noted, which is the intrinsic value of workplace learning. Eraut and Hirsh (2007) and Lester and Costly (2010) suggest that the most effective and valuable learning for employed individuals is often that which occurs through the workplace. In the UK, as in many other advanced economies, there is an emerging consensus that the number of people in the workforce with higherlevel skills needs to be increased substantially (HM Treasury, 2006) and that this cannot be achieved by 
growth in the number of full-time students alone. As a result, universities are being encouraged to increase their involvement in workforce development and look beyond school-leaver and early-career markets, in order to engage with a wider range of adult learners and their employers.

Park and Choi (2016) highlight the correlation between workplace learning and job performance but note that organisations have a responsibility to ensure their employees' learning at work is valuable if it is to yield an increase in performance. This responsibility has to be mirrored by education providers if apprenticeships are to be valued by employers and by apprentices alike. It is this notion of learning at work that represents a shift in paradigm for universities which recognise the value of work-based learning as part of academic programmes.

Apprenticeship programmes are not unique to England, indeed many countries around the world have formal apprenticeship programmes although they vary widely in their nature and most are linked to a national system which provides a legislative and regulatory framework governing their operation. Smith (2016) notes that while the term apprenticeship can be interpreted in many different ways, apprenticeships are generally understood to have similar characteristics including the combination of 'off' and 'on' the job training, an assumption that employers are responsible for the development of the apprentice and the award of a qualification or licence to practice upon successful completion.

The German system is commonly regarded as the 'gold standard' for apprenticeships (Pilz and Li, 2014; Deissinger, 2015) but like in England, the apprenticeship programmes in Australia, Germany and Switzerland are undergoing change. Both Germany and Switzerland have recognised the need to strengthen the apprenticeship system and develop pathways for progression into higher education, choosing to view HE as complementary sub-systems of the vocational education system. Yet, Germany and Switzerland are both grappling with what Gonon and Deissinger (2016) call the academic fallacy and the new rise of meritocratic thinking resulting from vocational training permeating the sacred world of higher education. It is too early to ascertain how English universities will respond to degree level apprenticeships but what is important to note is that the involvement of higher education in apprenticeships is being considered globally.

\section{Accountability Frameworks}

Apprenticeship delivery is predicated on a tri-partite model focusing on the learner, the college or training provider of the qualification and the employer. Until recently, the role of the employer was largely passive as they were facilitators of the apprenticeship programme by enabling learners to gain the necessary skills and competencies required. However, the government's proposed Apprenticeship Levy (HM Revenue and Customs, 2016) will require employers to pay annually into a government fund which they can then draw upon to 'purchase' apprenticeships for new and existing staff. This shifts the responsibilities on employers from passive recipients of apprentices to commissioners of apprenticeships for their staff thus placing a level of responsibility on them to ensure that apprenticeship delivery is meeting the needs of the student and the organisation.

Nonetheless, these developments must be seen as part of wider reforms based on neo-liberal values of a state funded system of quasi-independent education providers responsive to market forces and competition which would, it was believed, improve the performance of apprenticeship providers by becoming directly accountable to service users. Education could no longer be a 'secret garden' of an 
autonomous professional community detached from public scrutiny: state funded education had to become publicly accountable (Ranson, 2003).

Poulson (1998) argues that few people would disagree with increased accountability being a good thing or that standards in education should be raised. However, accountability is a multi-layered concept defining a formal relationship between the training provider and learner, and an informal relationship between training provider and employer, where one is mandatorily held to account by the other. This locates accountability in a hierarchical bureaucracy, with apprenticeship assessors and tutors being accountable to the head of the training organisation, who is accountable to the governing body and to the public accounts committee and in turn to the secretary of state for education (a job within the British government reporting to the Prime Minister). From the employer's perspective, there is no formal accountability framework either for existing or the new degree level apprenticeships; however, this rather simplistic view of accountability does not acknowledge the complexities of the relationships involved.

If tutors and assessors are accountable in this hierarchical bureaucracy, one would assume they are also accountable to the employer of the apprentice for the progress of the apprentice's learning, yet, their first accountability must be to their own employer (the training provider). Following this line of argument, if tutors and assessors are held accountable, should accountability be reciprocal with an expectation that apprenticeship employers reinforce the learning process? This shifts the role of apprentice employer from one which is largely passive to one which holds the employer accountable for the progress of their apprentices.

In order to try and address this the UK Government's vision for English apprenticeships by 2020 (BIS, 2015a) states that all parties (employer, training provider and apprentice) must sign a 'Statement of Commitment'. This statement (SFA, 2016) supplements the Apprenticeship Agreement, which is the legal contract between the employer and the training provider, and outlines the roles and responsibilities of the employer as well as the training provider. Saying that, the statement of commitment does not go far enough as holding employers to account but simply states: the employer's commitment to wages and time off to study during the working day; the support and guidance available from the training provider and how to access it; and the apprentices' study details.

If employers are to have an active role in apprenticeships, should they not be intrinsically involved in the delivery of the curriculum and assessment? This is not to say that they are not involved in these areas, but it is often informal ad-hoc learning in order to demonstrate a particular skill and then checking that a learner is undertaking the task correctly rather than formalised structured learning as part of the main qualification. Such complexity of accountability denies a simple linear hierarchical accountability framework, due to the training relationship going beyond that of the tutor and student to a tri-partite arrangement involving the employer. As a result of this tri-partite approach, accountability for degree level apprenticeships appears not to fit the over-simplified linear hierarchical process.

Despite the complexities surrounding accountability and the prevailing need to ensure the quality of public services, Ranson (2003) argues that the only way forward is for a system which is open and transparent. But how do the government's aspirations for 3 million apprentices sit within this notion of accountability? Regardless of the constant talk of accountability and an extensive review of the literature, little exists on frameworks that define accountability from a conceptual basis. McLaughlin and Rhim (2007) state that accountability has become a fundamental feature of education policy in the UK, 
the USA, Australia and New Zealand; however, there has been a move to an outcomes-based measure, such as apprenticeship participation or success rates.

This is a departure from past notions of accountability that have focused on inputs, such as fiscal resources or compliance with rules and procedures. Anderson (2005) proposed that education accountability systems are multi-dimensional with three key facets: compliance and regulation, adherence to professional norms and results. McLaughlin and Rhim (2007), on the other hand, suggest that there are only two dominant forms of accountability: Standards-Driven Accountability and MarketDriven Accountability. The difference between the current systems of accountability and those previously employed focus largely around the purpose of the systems and for whom they are designed. One of the elements of Anderson's (2005) model is the focus on compliance and regulation, for example, are apprenticeship requirements being adhered to in terms of learner eligibility or curriculum delivery requirements? This is what McLaughlin and Rhim (2007) call input-based accountability, rather than outcomes-based which is where accountability frameworks seemingly have evolved to.

This paper has already discussed the shift in role for employers and as a result of this, state-led regulation has increased as a mechanism by which quasi-autonomous education and training providers and the autonomous employer can be directed to continue to meet the apprenticeship aspirations of successive governments. This is an example of how the state has used input based accountability to meet its own political agenda.

This reinforces Anderson's first dimension and emphasises the need for an element of input-based accountability despite the preference of western governments towards solely an outcome-based approach to accountability. Anderson (2005) also suggests that accountability should be based on professional norms which focus on standards in education. Currently, education standards in the UK are monitored through a state-led inspection regime conducted by the office for standards in education (Ofsted). In the context of the new degree level apprenticeships, qualification standards are not nationally monitored to the same extent as they are in further education which is regulated by the office of qualifications and examination regulation (Ofqual) and Ofsted. The Quality Assurance Agency, (QAA) is entrusted with monitoring and advising on standards and quality in UK higher education but using a very different framework from the one used by Ofsted. However, the Higher Education Funding Council for England (HEFCE), the organisation responsible for funding higher education, recently consulted on a revised quality assurance system for 2017/18 which places greater emphasis on student outcomes from higher education providers rather than process, as per the current arrangements (HEFCE, 2015). This emphasis on outcomes aligns the approach taken by Ofsted and can be described as outcome-based accountability (McLaughlin and Rhim, 2007). This raises questions about whether the professional norms which Anderson (2005) advocates are achievable and if, as Ranson (2003) suggests, we need a system which is open and transparent, how can it be facilitated.

The publication of Ofsted inspection reports and an individual education and training provider's performance data on a publically searchable website is what McLaughlin and Rhim (2007) and Glatter (2012) define as Market-Driven accountability, where there is an expectation that market forces such as choice and competition will, in theory, incentivise providers to improve standards. The focus here remains on holding education providers accountable for apprenticeship performance and lacks any form of accountability for employers. McLaughlin and Rhim's (2007) and Glatter's (2012) ideas are different to Anderson's ideas which use outcome measures to judge standards rather than market forces. As apprenticeship delivery relies on a tri-patriate model (learner, education or training provider and 
employer) each person or element must be axiomatically responsible for standards and attainment through an agreed process of internal monitoring.

Another approach to accountability is the move towards a results driven system. Possibly the most publicised accountability measure, it seeks to make tutors and assessors accountable for both student outcomes and timely completion of apprenticeships and, to the general public for institutional performance. This form of accountability is what McLaughlin and Rhim (2007) call outcome-based accountability, yet Isaacs (2012) argues that new and changing accountability frameworks for colleges and training providers are being introduced as a result of wider curriculum reforms such as the move from the apprenticeship requirements set out in the Apprenticeship, Skills Children and Learning Act (2009) to those in the Specification of Apprenticeship Standards for England (SASE). While these accountabilities are talked about as new, there is no clear distinction between what Isaacs suggests and results-driven accountability of Anderson's (2005) model and that of McLaughlin and Rhim's (2007). Glatter (2012) suggests that results-driven accountability is the UK government's instrument of choice for control and uses the combination of subjective Ofsted inspections with graded outcomes, alongside performance tables which allow members of the public to compare institutions on purely statistical indicators. At the same time, the removal of contextual data provides a distorted view of institutional performance in relation to individual learners. Similar accountability systems are in place in many European countries, for example, in Germany, the Federal state implements a nationally regulated quality improvement system, whereas in Italy the shift has been made to a quality improvement system from an approach predicated on quality control. On the other hand, O'Neill (2002) argues that this may afford the government with an ease of measurement and control rather than an accurate measurement of performance. This element incorporates what McLaughlin and Rhim (2007) propose to be standardsdriven accountability which measures the extent to which students meet performance expectations and on its own creates an accountability system purely based on assessments. The combined use of performance indicators and narrative inspection reports provide an accountability system built around Anderson's (2005) three pillars, rather than the single-dimension approach proposed by other systems.

However, there are some potential challenges with the current system of accountability afforded to state-funded institutions in England. First, it is dependent on who funds degree level apprenticeships. Traditionally degrees delivered in universities are funded through the Higher Education Funding Council for England (HEFCE) or if through a further education college then by the college either holding a funding contract directly with HEFCE or through a franchise arrangement with a university. Historically, apprenticeships were further education qualifications and as such funded by the Skills Funding Agency (or one of the predecessor organisations), but the new degree level apprenticeships are not being funded through HEFCE but instead through the Skills Funding Agency using their Adult Skills Budget which was reduced in 2015 by $3.9 \%$ on top of the previous reductions totalling $24 \%$ (Whittaker, 2015). This raises questions about the viability of degree level apprenticeships and whether the proposed apprenticeship levy will cover the full cost of apprenticeship delivery. So, the funding for degree apprenticeship is through the government agency which does not normally fund degree level provision and the accountability for non-degree level apprenticeships rests with Ofsted and Ofqual, which does not have jurisdiction over degree providers. Second, Gilroy and Wilcox (1997) argue that the current inspection process is fundamentally flawed, as it is a subjective process requiring a quantitative judgement to be made based on primarily qualitative data. Again, this only applies to further education and not higher education qualifications, thus rendering existing accountability frameworks potentially null for degree apprenticeships. It is beyond the scope of this paper to provide an analysis of current inspection regimes from different countries but it is important to acknowledge that the system used in England is not without its critics (Ball, 2003; Perryman, 2007). 
Third, there is the risk of increased stress on apprenticeship tutors and assessors through the preoccupation of strategies targeting borderline grade students in order to improve an institution's apprenticeship success rates, what Glatter (2012) refers to as gaming. While Leckie and Goldstein (2011) argue that performance or 'league' tables are not a reliable indicator of performance, suggesting instead that the main purpose of constructing performance tables should be for institution-based accountability and contend that, instead of being the end result they should be used as an internal monitoring tool to identify areas for further investigation. Whether accountability frameworks focus on one discrete area such as standards-driven accountability or market-driven accountability or try to combine a range of foci as adopted by Anderson's (2005) framework, they are each open to challenges around their appropriateness. McLaughlin and Rhim (2007) suggest looking beyond the detail of each framework and for consideration to be given to whether the chosen framework fulfils its potential by improving outcomes for apprentices. Dyson et al. (2010) have argued that accountability should not be confined to one single dimension, be it input focused such as compliance or output orientated as in standardsdriven or market-driven accountability, but instead to be explicitly multidimensional, allowing for greater dialogue between all parts of the education system (universities and further education providers) and with all interested stakeholders (employer representatives). This would require a significant departure from the currently top-down imposed system of control to one which processes elements of bottom-up and horizontal as well as top-down accountability.

The challenge facing the education component of the degree-level apprenticeship framework is despite education and training providers developing the plethora of strategies aimed at improving results and boost their position in performance tables, what Anderson (2005) describes as results based accountability and McLaughlin and Rhim (2007) call outcome-based accountability, the existing accountability frameworks will make education and training providers accountable for apprentices whom they potentially have only limited contact with, compared to that of the employer. Also, degree level apprenticeships are an example of how the government is trying to apply existing accountability frameworks such as Anderson's (2005) compliance and regulation dimension of accountability and McLaughlin and Rhim's (2007) input based element to enforce their aspiration of 3 million apprentices by 2020 .

This paper highlights the fact that the discourse needs to continue and advocates that institutions need to jointly consider with employers how they can best support the government's aspirations without neglecting their responsibility to the apprentice. Glatter (2012) and Waslander et al. (2010) argue that this form of performance indicator is a prime example of the government's use of decontextualized knowledge which ignores a range of contextual factors including geographic and socioeconomic characteristics of the local area. As institutions grapple with the new degree level apprenticeships one may witness a further blurring of an institution's boundary in relation to the responsibility and accountability for apprentices when they are funded by government agencies not familiar with degree programmes.

\section{Conclusions}

This paper has suggested that careful consideration is needed regarding how current notions of accountability are applied to degree-level apprenticeship, given the differences between existing further education delivery providers and higher education. At the same time, reflexion is required on the role of employers in supporting apprentices as they not only enter the apprenticeship programme but also 
transition from the other end having secured their apprenticeship qualification and ultimately moved onto professional status. The introduction of the apprenticeship levy places the accountability for the commissioning of degree level apprenticeships firmly on the employer. Yet, current accountability systems do not hold employers to account either axiomatically for apprenticeship delivery or the use of public monies. Only once these issues have been considered, in terms of the policy context and argument put forward in this paper as well as the economic and demographic context of the local area, will stakeholders be able to make an informed choice as to how to best support apprenticeships.

Despite the aforementioned challenges around the accountability system for degree level apprenticeships which are not insurmountable, they will require all parties to be clear on their own roles and responsibilities in the delivery of the programme. At the same time, an understanding of the shared responsibility employers and training providers have towards the learner regarding their progress is needed. While the government requires all parties to sign a Statement of Commitment, this is insufficient in meeting the challenges highlighted in this paper. It would be prudent for those involved in apprenticeship delivery to develop the aforementioned statement into a document which clearly articulates the roles, responsibilities and accountabilities of all parties. Not only will the new degree level apprenticeships offer a progression route for individuals who have completed apprenticeships at level 3 , it has the potential to more closely align qualifications delivered by universities with the business needs of local regional and national employers. Whether this will simply displace learners who would have normally followed a traditional degree, it is too early to tell, but considering recent reductions in government funding, should perhaps degree-level apprenticeship be seen as an alternative to government funding, particularly if the apprenticeship levy is used to cover the full cost of apprenticeship delivery?

\section{References}

Anderson, J.A. (2005), Accountability in Education, The International Academy of Education, Belgium.

Anderson, A., Bravenboer, D., and Hemsworth, D. (2012), The role of universities in higher apprenticeship development. Higher Education, Skills and Work-based Learning. Vol. 2, No. 3, pp. 240255.

BIS (2011), Higher Education: Students at the Heart of the System, White Paper, BIS, London.

BIS (2012), Airline pilot apprenticeships take off. BIS press release, 22 June, available at:

https://www.gov.uk/government/news/airline-pilot-apprenticeships-take-off

BIS (2015), The future of apprenticeships in England, BIS, London.

BIS (2015a), English Apprenticeships: our 2020 vision, BIS, London.

BIS (2016), The future of apprenticeships in England. Guidance for trailblazers - from standards to starts, BIS, London.

Brookmann, M., Clarke, L., and Winch, C. (2010), Constructing learning: Adversarial and collaborative working in the British construction industry. Journal of Education and Work. Vol. 23, pp 111-127. 
Deissinger, T. (2015), The German dual vocational education and training system as "good practice". Local Economy, Vol 30, No. 5, pp.557-567

Delebarre, J. (2015), Apprenticeships Policy, England 2015 (briefing paper 03052) House of Commons Library. $8^{\text {th }}$ March 2016.

Eraut, M., and W. Hirsh. (2007), The significance of workplace learning for individuals, groups and organisations. Oxford, UK: University of Oxford

Fuller, A., and Unwin, L. (2012), Banging on the door of the university: the complexities of progression from apprenticeship and other vocational programmes in England. Cardiff: ESRC Centre on Skills, Knowledge and Organisational Performance (SKOPE).

Glatter, R. (2012), Persistent preoccupations: the rise and rise of school autonomy and accountability in England, Educational Management and Leadership, Vol. 40, No. 5, pp.559-575.

Gonon, P., and Deissinger, T. (2016), Stakeholders in German and Swiss vocational education and training systems - their role in innovating apprenticeship against the backdrop of academisation. Education and Training, Vol. 50, No. 58.

Higher Education Funding Council for England (HEFCE) (2015), Future approaches to quality assessment in England, Wales and Northern Ireland. Analysis of responses to consultation, (HEFCE 2015/30). Bristol, HEFCE.

Hillman, N. (2015) It's the finance, stupid! The decline of part-time higher education and what to do about it. Higher Education Policy Institute, Oxford, UK.

HM Revenue and Customs (2016), Apprenticeship Levy. HMRC, London.

HM Treasury (2006), Leitch Review of Skills: Prosperity for all in a global economy - world class skills. HMSO, London.

Isaacs, T. (2012), New Accountability Frameworks for Schools and Colleges, Institute of Education, London, UK.

Lester, S. and Costley, C. (2010). Work-based learning at higher education level: value, practice and critique. Studies in Higher Education, Vol. 35, No. 5, pp.561-575

McLaughlin, A. and Rhim, L.M. (2007), Accountability frameworks and children with disabilities: a test of assumptions about improving public education for all students, International Journal of Disability, Development and Education, Vol. 54, No. 1, pp.25-49.

National Apprenticeship Service [NAS] (2011), Higher Apprenticeship Fund Prospectus, NAS, Coventry.

OECD (2014). G20-OECD-EC Conference on quality apprenticeships for giving youth a better start in the labour market. OECD Conference Centre, Paris, $9^{\text {th }}$ April 2014.

Park, Y. and Choi, W. (2016) The effects of formal learning and informal learning on job performance: the mediating role of the value of learning at work. Asia Pacific Education Review, Vol 17, No. 2, pp 279287. 
Pilz, M., and Li, J., (2014), Tracing teutonic footprints around the world? The skills development strategies of German companies in the USA, China and India, European Journal of Training and Development, Vol 38, No. 8, pp745-763.

Poulson, L. (1998), Accountability, teacher professionalism and education reform in England, Teacher Development, Vol. 2, No. 3, pp.419-432.

Ranson, S. (2003), Public accountability in the age of neo-liberal governance, Journal of Education Policy, Vol. 18, No. 5, pp.459-480.

SFA (2016), Apprenticeship standards funding rules 2016 to 2017, Skills Funding Agency, London, UK.

Smith, E. (2016), Apprenticeship management at national and company levels: research based 'good practice' principles. International Journal of HRD, Policy and Research, Vol 1, No. 1, pp.35-52.

UK Commission for Employment and Skills (UKCES). (2012) Grow Your Own How young people can work for you in England. UKCES, London, UK.

UK Commission for Employment and Skills (UKCES). (2015) Employer Skills Survey 2015. Skills in the labour market. UKCES, London, UK.

Universities UK. (2016), The future growth of degree apprenticeships. Universities UK, London, UK.

Waslander, S., Pater, C and van der Weide, M. (2010), Markets in education: an analytical review of empirical research on market mechanisms in education. Available online at: http://www.oecdilibrary.org/education/markets-in-education_5km4pskmkr27-en (accessed 18th April 2016).

Whittaker, F. (2015), SFA confirms further 3.9 per cent ASB cut as in-year departmental savings bite. FE Week [accessed $18^{\text {th }}$ April 2016] available online at: http://feweek.co.uk/2015/07/21/sfa-confirmsfurther-3-9-per-cent-asb-cut-as-in-year-departmental-savings-bite/

Williams, C., and Hanson, W. (2011), Higher Apprenticeships and Professional Bodies. PARN, Bristol. 